\title{
REVIEW
}

\section{Update on the genotoxicity and carcinogenicity of cobalt compounds}

\author{
D Lison, M De Boeck, V Verougstraete, M Kirsch-Volders
}

\begin{abstract}
Objective-To integrate recent understandings of the mechanisms of genotoxicity and carcinogenicity of the different cobalt compounds.

Method-A narrative review of the studies published since the last IARC assessment in 1991 (genotoxicity, experimental carcinogenesis, and epidemiology).

Results-Two different mechanisms of genotoxicity, DNA breakage induced by cobalt metal and especially hard metal particles, and inhibition of DNA repair by cobalt (II) ions contribute to the carcinogenic potential of cobalt compounds. There is evidence that soluble cobalt (II) cations exert a genotoxic and carcinogenic activity in vitro and in vivo in experimental systems but evidence in humans is lacking. Experimental data indicate some evidence of a genotoxic potential for cobalt metal in vitro in human lymphocytes but there is no evidence available of a carcinogenic potential. There is evidence that hard metal particles exert a genotoxic and carcinogenic activity in vitro and in human studies, respectively. There is insufficient information for cobalt oxides and other compounds. Conclusion-Although many areas of uncertainty remain, an assessment of the carcinogenicity of cobalt and its compounds requires a clear distinction between the different compounds of the element and needs to take into account the different mechanisms involved. (Occup Environ Med 2001;58:619-625)
\end{abstract}

Dr D Lison

lison@toxi.ucl.ac.be

Accepted 17 April 2001

Keywords: cobalt; DNA breakage; inhibition of DNA repair

Table 1 Main industrial applications of cobalt and its compounds

\begin{tabular}{ll}
\hline Industrial applications & Cobalt species involved \\
\hline $\begin{array}{l}\text { Cobalt refining } \\
\text { Special alloys (superalloys, magnets, high strength } \\
\text { stellite, ...) }\end{array}$ & $\begin{array}{l}\text { Cobalt metal, oxides, and salts } \\
\text { Cobalt metal + other metals (Ni, Cr, Y, } \\
\text { Sr, ...) }\end{array}$ \\
Hard metal (cemented carbides) production & $\begin{array}{l}\text { Homogeneous phase } \\
\text { Cobalt metal + carbides }\end{array}$ \\
Diamond polishing & $\begin{array}{l}\text { Heterogeneous phase } \\
\text { Diamond particles, iron + cobalt metal }\end{array}$ \\
Oil refining & $\begin{array}{l}\text { Heterogeneous phase } \\
\text { Cobalt oxides and salts }\end{array}$ \\
Drying agents (paints, varnishes, inks) & Cobalt organic compounds \\
Pigments, enamels & Cobalt oxides and salts \\
Batteries & Cobalt oxides \\
Catalysts & Cobalt inorganic and organic salts \\
Fluorination & Cobalt fluoride \\
\hline
\end{tabular}

Main messages

- The evaluation of the carcinogenicity of cobalt and its compounds requires a clear distinction between the different compounds of the element and needs to take into account the different mechanisms involved.

- Contrary to what is generally assumed for most metals, the biological activity of cobalt metal is not exclusively mediated by the ionic form dissolved in biological media.

- There is a need for an experimental and epidemiological assessment of the genotoxicity and carcinogenicity of cobalt oxides.

Cobalt and several of its compounds are used in various industrial applications (table 1). Workers are mainly exposed to cobalt by inhalation and varying toxic manifestations affecting the respiratory system have been reported in these industries. Diseases of the upper respiratory tract, the bronchial tree, and the lung parenchyma have been reported and reviewed. Some manifestations are associated with specific industrial settings involving exposure to a specific type of cobalt compound. It has for instance been shown, both epidemiologically and experimentally, that the occurrence of a fibrosing alveolitis is specifically associated with the hard metal industry (hard metal disease) where exposure is to a mixture of cobalt metal and carbide particles. Other manifestations - such as bronchial asthmaseem to be associated with many industrial applications, irrespective of the chemical or physical form of cobalt. Dermal exposure has also been reported and may contribute to the development of allergic reactions. ${ }^{2}$

The carcinogenic potential of cobalt and its compounds was evaluated by IARC in $1991,{ }^{3}$ which concluded that there was inadequate evidence for carcinogenicity in humans (lung cancer) but sufficient evidence in experimental

Policy implication

- The evaluation of the carcinogenic potential of metallic elements cannot be limited to a generic statement or classification. 
animals. In most experimental studies considered, the routes of exposure used to produce an excess of tumours were, however, of questionable relevance for assessing the risk of cancer in humans-for example, local sarcomas after intramuscular injection. The overall generic evaluation was that cobalt and its compounds are possibly carcinogenic to humans (group 2B). In the same evaluation, cobalt (II) compounds were reported to induce DNA damage, DNA protein cross links, gene mutations, sister chromatid exchanges, and aneuploidy in in vitro studies on animal and human cells. There was some evidence that these compounds could also induce aneuploidy in vivo in Syrian hamster bone marrow and testes. ${ }^{3}$

Since this evaluation, additional data have been accumulated which, as for many other elements (antimony, arsenic, beryllium, chromium, lead, nickel, silicon, etc), generally underline that the species of cobalt have different influences on the toxicity, mutagenicity, and carcinogenicity. Therefore it is important to better differentiate the varying compounds of the element to refine the assessment of the carcinogenic hazard. Several recent data indicate that indeed variations in the response exist according to the cobalt species considered-for example $(a)$ in vitro studies have provided further evidence that cobalt (II) ions can affect DNA integrity either directly by the induction of DNA breaks or indirectly through inhibition of specific repair systems, (b) inhalation of cobalt sulphate produced a clear carcinogenic response in two experimental animal species, (c) cobalt metal particles have biological activities which are not mediated by cobalt (II) ions, and $(d)$ when mixed with metallic carbide, cobalt metal has different genotoxic and carcinogenic properties and needs to be considered as a specific toxic entity (hard metal particles).

The purpose of this overview is to integrate our recent understanding of the mechanisms of genotoxicity and carcinogenicity of the different cobalt compounds. The evaluation will focus on studies published since the last IARC evaluation and particular emphasis will be placed on two different mechanisms of genotoxicity and carcinogenicity, DNA breakage, and inhibition of DNA repair, which may contribute to explain the carcinogenic potential of cobalt compounds.

\section{Cobalt ions}

Recent experimental studies have brought additional data which contribute to better delineate the molecular mechanisms involved in the genotoxic and carcinogenic potential of cobalt ions. These mechanisms may conceivably apply both to soluble cobalt compoundsfor example, cobalt chloride or sulphate-and also to cobalt metal or hard metal particles which are readily solubilised in biological media. In vivo, however, the bioavailability of cobalt (II) is relatively limited because these cations precipitate in the presence of physiological concentrations of phosphates $\left(\mathrm{K}_{\mathrm{sp}}\right.$ $2.5 \times 10^{-35}$ at $25^{\circ} \mathrm{C}$ ) and bind to proteins such as albumin. ${ }^{4}$
GENOTOXICITY

In vitro, in mammalian cells, two mechanisms seem to apply.

Some studies indicate a direct effect of cobalt (II) ions to damage DNA through a Fenton-like mechanism

It has been shown in vitro in human lymphocytes and isolated DNA that, in the presence of hydrogen peroxide, micromolar concentrations of cobalt (II) ions are able to cause chemical damage to DNA bases in chromatin, probably through the production of hydroxyl radicals. ${ }^{5-7}$ The generation of reactive oxygen species by cobalt (II) from $\mathrm{H}_{2} \mathrm{O}_{2}$ and related in vitro DNA damage was further investigated by Mao et al with electron spin resonance, electrophoretic assays, and high performance liquid chromatography. These authors have shown that the oxidation potential of cobalt (II) can be modulated by chelators to facilitate or reduce its capacity to generate reactive oxygen species from hydrogen peroxide $\left(\mathrm{H}_{2} \mathrm{O}_{2}\right)$-for example, anserine enhanced the capacity of cobalt (II) to generate radicals, deferoxamine reduced it. Cobalt ions were also shown to substitute for zinc in protein-zinc finger domains which control the transcription of several genes. This substitution is suggested to generate free radicals close to DNA, causing DNA damage. ${ }^{9}$

Other studies indicate that cobalt ions affect the repair of DNA damage induced by other agents in mammalian cells

In vitro, ionic cobalt (II) $(75 \mu \mathrm{M} \mathrm{CoCl})$ was shown to inhibit nucleotide excision repair processes after ultraviolet (UV) irradiation as measured by the alkaline unwinding method. ${ }^{10}$ A concentration as low as $50 \mu \mathrm{M} \mathrm{CoCl}_{2}$ inhibited the incision as well as the polymerisation step of the DNA repair process in human fibroblasts treated with ultraviolet light. ${ }^{11}$ As the repair of DNA damage is an essential homeostatic mechanism, its inhibition may account for a mutagenic or carcinogenic effect of cobalt (II) ions. Concentrations less than 1 $\mathrm{mM} \mathrm{CoCl} \mathrm{Cl}_{2}$ did not affect the actvity of the bacterial formamidopyrimidine-DNA glycosylase (Fpg) but significantly reduced the DNA binding ability of the mammalian damage recognition protein XPA. ${ }^{12}$ Competition with essential magnesium ions ${ }^{11}$ and binding to zinc finger domains in repair proteins were identified as a potential mode of indirect genotoxic activity of cobalt (II) ions. It has also been reported that the DNA binding capacity of the $\mathrm{p} 53$ protein, which is a zinc dependent mechanism, can be modulated by cobalt (II) ions. ${ }^{13}{ }^{14}$

In vivo, intraperitoneal administration of cobalt(II) ions in the rat (50 or $100 \mu \mathrm{mol}$ cobalt acetate $/ \mathrm{kg}$ ) produced oxidative DNA damage in renal, hepatic, and pulmonary chromatin. The altered bases identified were typical products of hydroxyl radical attack on DNA, supporting the Fenton-like mechanism, and some of them have been shown to be promutagenic. ${ }^{15}$ It is likely that this in vivo effect is dependent on the presence of endogenous 
concentrations of hydrogen peroxide or biological ligands in target tissues because in vitro, in the absence of hydrogen peroxide, cobalt (II) ions up to a concentration of $0.1 \mathrm{mM} \mathrm{CoCl}_{2}$ did not induce DNA single strand breaks in human lymphocytes or purified DNA. ${ }^{16}$ The DNA breakage was, however, detected by De Boeck et $a l^{17}$ with the comet assay in human lymphocytes exposed to non-cytotoxic concentrations of $\mathrm{CoCl}_{2}(0.1 \mathrm{mM})$. Further studies are therefore needed to clarify these discrepancies; special attention should in particular be given to control the presence of ligands-for example, chelators, proteins - which may modulate the bioavailablility or activity of cobalt (II) ions.

Chromosomal aberrations have also been found in bone marrow cells of mice after a single oral administration of relatively high doses of cobalt chloride $(20,40$, or $80 \mathrm{mg} / \mathrm{kg}$, lethal dose required to kill $\left.50 \%\left(\mathrm{LD}_{50}\right) 800 \mathrm{mg} / \mathrm{kg}\right){ }^{18}$

It should also be mentioned that in vivo administration of cobalt chloride stimulates the synthesis of erythropoietin, ${ }^{19}$ which might lead to an increased sensitivity of proliferating erythroblasts to mutagenic damage, as assessed by the micronucleus test in polychromatic erythrocytes. $^{20}$

\section{CARCINOGENICITY \\ Experimental}

A recent national toxicology programme study reported clear evidence of carcinogenicity of cobalt sulphate heptahydrate both in $\mathrm{B} 6 \mathrm{C} 3 \mathrm{~F} 1$ mice and $\mathrm{F} 344 / \mathrm{N}$ rats after 2 years of exposure by inhalation $\left(0.3,1\right.$, and $3 \mathrm{mg} / \mathrm{m}^{3}$ or 60,200 , and $\left.600 \mu \mathrm{g} \mathrm{Co} / \mathrm{m}^{3}\right) .{ }^{21}$ In rats, proteinosis, alveolar epithelial metaplasia, granulomatous alveolar inflammation, and interstitial fibrosis were found in the lung of all exposed groups (no observed effect level (NOEL) $<0.3 \mathrm{mg} / \mathrm{m}^{3}$ ). Hyperplasia of the respiratory epithelium of the larynx and atrophy of the olfactory epithelium were found in all exposed groups. Squamous metaplasia of the respiratory epithelium was also found in the nose and larynx of exposed rats. In mice, non-neoplastic lesions of the respiratory tract were less severe than in rats.

The incidence of alveolar or bronchiolar neoplasms was significantly increased in rats exposed to 1 and $3 \mathrm{mg} / \mathrm{m}^{3}$ (with a significant dose-response relation), and in the group of mice exposed to $3 \mathrm{mg} / \mathrm{m}^{3}$ (NOEL lung carcinogenicity $0.3 \mathrm{mg} / \mathrm{m}^{3}$ in rats; $1 \mathrm{mg} / \mathrm{m}^{3}$ in mice).

Besides the genotoxic activity of cobalt (II) cations already discussed, it should also be considered that recent work on the lung toxicology of inhaled particles has provided evidence that carcinogenicity could also be mediated by activated oxygen species released by inflammatory cells (macrophages, polymorphonuclear neutrophils) recruited in the lung. ${ }^{22}$ It can therefore not be formally excluded that inflammatory responses induced by cobalt (II) sulphate may have contributed to this carcinogenic response.
Overall, it can be concluded that the genotoxic potential of cobalt (II) cations is demonstrated in vitro and, despite their theoretically limited bioavailability in biological fluids, there is evidence that cobalt (II) cations exert genotoxic as well as carcinogenic effects in animals. It seems reasonable to consider that all soluble cobalt (II) salts (chloride, sulphate, acetate) share this carcinogenic potential. There is, however, no evidence of genotoxicity or carcinogenicity available in humans.

In line with these conclusions, the specialised experts of the European Union have classified cobalt chloride and sulphate as C2 carcinogens (labelled R49).

\section{Cobalt metal}

Until recently, very little was specifically known about the toxicology of cobalt metal particles, probably because it was assumed, as for other metals, that the biological activity of a metal, including genotoxicity and carcinogenicity, was mediated by the ionic form and could be apprehended by testing soluble compounds. We have shown in vitro that at least some biological activities of cobalt metal particles could not be explained by the presence of solubilised cobalt species. ${ }^{23}$ Further physicochemical studies have shown that cobalt metal, and not its (II) ionic species, is thermodynamically able to reduce oxygen in activated oxygen species; the kinetics of this process is, however, slow as a result of the poor oxygen binding capacity at the surface of cobalt metal particles. ${ }^{24}$ It is worth noting that, in this system, soluble cobalt ions are produced during but do not drive the critical reaction; so activated oxygen species are not produced by a Fenton-like reaction as described with cobalt ions in the presence of hydrogen peroxide. ${ }^{8}$ Therefore, it is important to recognise that, contrary to what is generally hypothesised for most metals, the biological activity is not exclusively mediated by the ionic form dissolved in biological media. The discovery of this new mechanism of action of a metallic species allows new interpretations of its biological activity and further underlines that it would be inappropriate to assume that all cobalt compounds exert similar biological activities because they are all to some extent converted in cobalt cations in vivo.

\section{GENOTOXICITY}

In vitro studies with the alkaline elution and comet assays have shown that non-cytotoxic doses of cobalt metal (Co, 1.5-15 $\mu \mathrm{g} / \mathrm{ml}$ ) induce alkali labile sites or DNA strand breaks in isolated DNA and cultured human lymphocytes and these DNA damages could be partially blocked by scavenging of activated oxygen species. Cobalt chloride up to $0.1 \mathrm{mM}$ did not produce significant DNA breaks in this system. ${ }^{16}$ Dose-effect relation and time dependency of the DNA breaks induced by cobalt metal particles were further analysed with the alkaline comet assay. ${ }^{17}$ The amount of induced breaks increased with concentration of cobalt and with duration of exposure. The genotoxic activity of cobalt metal particles 
$(0.6-6 \mu \mathrm{g} / \mathrm{ml}))$ has been confirmed by the cytokinesis blocked micronucleus test in human lymphocytes in vitro. ${ }^{25}$

The interference of cobalt particles with the repair of mutagen induced DNA damage was also investigated by treating human lymphocytes with methyl methanesulfonate (MMS). After removal of MMS, the cells were further incubated in the absence or presence of cobalt metal particles. These studies indicated that cobalt metal particles increased the persistence of MMS induced DNA lesions as measured by the comet assay. ${ }^{17}$

Cobalt particles can therefore affect the integrity of DNA both by producing activated oxygen species (a process independent of the cobalt (II) species) and by inhibiting the base excision repair system (a process probably depending on the cobalt (II) species solubilised from the cobalt particles).

A biomonitoring study ${ }^{26}$ was recently conducted to assess genotoxic effects as a measure for carcinogenic risk in 35 workers from cobalt refineries exposed to an average cobalt dust concentration of $20 \mu \mathrm{g} / \mathrm{m}^{3}$, which is equivalent to the current threshold limit value time weighted average (TLV-TWA). ${ }^{27}$ The study design integrated methods to assess biomarkers of effects which represent both initial DNA damage (8-hydroxydeoxyguanosine (8OHdG), urinary excretion, and comet assay in lymphocytes) and definitive chromosome breakage or loss (micronuclei in lymphocytes). No significant increase in any genotoxicity biomarker was found in cobalt workers when compared with matched controls for age, smoking, and drinking habits.

\section{CARCINOGENICITY}

Experimental

In F344 rats, an intra-articular injection of cobalt-chromium-molybdenum powder (20 $\mathrm{mg} / \mathrm{rat}$ ) did not induce tumours locally or at distance after a duration of 24 months. ${ }^{28}$

\section{Epidemiology}

The follow up of a cohort of workers employed in an electrochemical plant producing cobalt and sodium, and previously studied from 1950 to 1980 by Mur et al, ${ }^{29}$ was extended for 7 additional years. ${ }^{30}$ The main result of the original study was a significant excess of lung cancer found among workers involved in the production of cobalt (standardised mortality ratio (SMR) $4.66,95 \%$ CI 1.46 to 10.64 , four cases observed). ${ }^{31}$ After this first analysis, the authors suggested that a complementary study should be undertaken before a firm conclusion could be drawn because (a) they could not take into account the consumption of tobacco, $(b)$ the observed number of cancer cases was low, and (c) simultaneous exposure to nickel and arsenic might have occurred. ${ }^{29}$ Extension of the follow up did not confirm the hypothesis of a relation between lung cancer and cobalt exposure (SMR 0.85 (95\% confidence interval $(95 \%$ CI) 0.18 to 2.50 , three cases observed). ${ }^{30}$ Explanations for the apparent discrepancy between the results from the first study and its update were proposed by Moulin et $a \beta^{30}$ : (a) no further death from lung cancer occurred among the workers during the additional 8 years of follow up; and (b) SMR in the update was based on three observed cases whereas the previous was based on four observed cases. This was due to the fact that data on causes of death were collected differently between the studies (death certificates instead of general practitioners' records, respectively). ${ }^{30}$

Overall, it can be concluded that although genotoxic effects of cobalt metal particles have been demonstrated in vitro in human lymphocytes, a single study of experimental carcinogenesis in the rat and epidemiology did not provide evidence of a carcinogenic potential for cobalt metal alone. No significant increase of genotoxic effects was detected in workers exposed to cobalt dust at a mean concentration corresponding to the current TLVTWA $\left(20 \mu \mathrm{g} / \mathrm{m}^{3}\right)$.

A well conducted inhalation carcinogenicity assay would help to clarify the carcinogenic potential of cobalt metal particles.

\section{Hard metals}

The recent demonstration of the capacity of hard metal particles to produce large quantities of activated oxygen species provides a new basis for interpreting their inflammatory action and their mutagenic and carcinogenic potential. With a spin trapping system applied to aqueous particulate suspensions and electrochemical techniques (already mentioned), it has been shown that the association of cobalt metal and carbide particles represents a specific toxic entity, producing larger amounts of activated oxygen species than cobalt metal particles alone. The mechanism of this interaction involves the oxidation of cobalt metal catalysed at the surface of carbide particles, reduction of dissolved oxygen into activated oxygen species, and production of soluble cobalt cations. ${ }^{24}$

\section{GENOTOXICITY}

In vitro, when tested over a range of cobalt equivalent concentrations $(1.5-15 \mu \mathrm{g} / \mathrm{ml})$, hard metal particles (tungsten carbide-cobalt metal (WC-CO) have been shown to cause significantly more (on average a threefold increase) DNA breaks than cobalt metal particles alone, both on isolated human DNA and in cultured human lymphocytes (alkaline elution and comet assays); this DNA damage was inhibited by scavenging activated oxygen species. ${ }^{16}$ As already mentioned, $0.1 \mu \mathrm{M} \mathrm{CoCl}_{2}$ did not cause DNA breaks in the same assay run in parallel. Dose dependency and time dependency of DNA breakage or alkali labile sites was shown for hard metal particles with the comet assay. ${ }^{17} \mathrm{~A}$ similarly greater genotoxic activity of hard metal compared with cobalt metal particles has been found with the cytokinesis blocked micronucleus test applied in vitro on human lymphocytes. ${ }^{25}$

It would be useful to confirm the genotoxic potential of hard metal particles in an in vivo model. However, systems to assess the genotoxic activity of inhaled particles in the lung tissue are not well validated. In a first attempt 
to assess their in vivo genotoxic potential, we have examined the capacity of cobalt and WC-Co particles to cause gene mutations in the big blue mouse bioassay but no induction of gene mutation was detected (unpublished observations). These findings need, however, to be interpreted with caution because of the relatively low sensitivity of this bioassay (spontaneous mutation rate of the lacI gene used as the reporter of the in vivo mutations, $5-10 \times 10^{-5}$ ). Therefore, there is clearly a need for further efforts to develop sensitive tests to assess the genotoxic potential of solid inhaled material such as cobalt and WC-Co particles.

The genotoxicity biomonitoring study already mentioned ${ }^{26}$ also included a group of 29 workers from hard metal producing plants exposed on the average to the current TLV-TWA for cobalt mixed with TC particles. Although a comparison with controls did not indicate an average increased genotoxic effect in those workers, a multivariate analysis showed that being a worker who smoked and was specifically exposed to hard metal dust (not cobalt alone) was a significant and positive determinant of two genotoxicity biomarkers (urinary $8 \mathrm{OHdG}$ and micronuclei). This finding is in line with the suggestion emerging from the French mortality study ${ }^{32}$ (discussed later) that smoking habits might interact with exposure to hard metal dust to increase the risk of lung cancer.

CARCINOGENICITY

Three mortality studies carried out in cohorts of workers from the hard metal industry have been published since the last IARC evaluation (table 2).

In Sweden, Hogstedt and Alexandersson $^{33}$ examined retrospectively (195182) a cohort of more than 3000 workers from one out of three plants in the country. There were 292 deaths among people under 80 years of age during the study period (SMR 0.96; 95\% CI 0.85 to 2.13 ). There were 17 cases of lung cancer versus 12.7 expected (SMR 1.34; $95 \%$ CI 0.77 to 2.13 ). Among those workers with more than 10 years employment who had died more than 20 years after the end of exposure, a significant excess mortality from lung cancer was found (seven cases observed versus 2.5 expected; SMR 2.78 95\% CI 1.11 to 5.72). Also, a tendency towards an excess of ischaemic cardiomyopathy and lung fibrosis was noted. No firm conclusion can be drawn from this single study due to the size of the population, which is relatively limited for a mortality study, and because the contribution of tobacco to both lung cancer and ischaemic cardiomyopathy could not be assessed individually. Although a previous study indicated that, on average, the smoking habits of hard metal workers were not different from those of the male Swedish population (Alexandersson, cited in IARC $1991^{3}$ ), it remains that a confounding effect of smoking cannot be excluded.

A mortality study ${ }^{34}$ in workers from the hard metal industry in France followed up from 1956 to 1989 showed an increased mortality from lung cancer (SMR 2.13, 95\% CI 1.02 to 3.93, 10 cases observed) which was related to the intensity of exposure (SMR 5.03 in the highest exposure group, $95 \%$ CI 1.85 to 10.95 , six cases observed). The excess lung cancer could not be explained by a confounding effect of smoking. ${ }^{34}$

This previous study has been extended to a cohort of 7459 workers from all hard metal plants in France $(n=13)$ followed up from 1968 to 1991 . The mortality from lung cancer in this cohort was significantly increased (SMR 1.30, $95 \%$ CI 1.00 to $1.66,63$ cases observed) and a relation with the intensity and duration of simultaneous exposure to cobalt metal and tungsten carbide particles was found. ${ }^{32}$ The results suggest the possibility of an interactive effect between exposure to hard metal and tobacco smoking (non-significant). An additional study conducted in one plant already included in the multicentre cohort does not provide additional insight into the carcinogenic activity of hard metal particles. ${ }^{35}$

Although in vivo evidence of the genotoxic activity of WC-Co particles is lacking, an overall evaluation of the studies already described strongly indicates evidence of carcinogenicity of hard metal particles in human mortality studies. It is important to recognise that hard metal particles constitute a distinct entity with a biological activity different from that of cobalt metal or cobalt cations; this distinct biological activity can be explained by a particular physicochemical mechanism of interaction between cobalt and WC particles. Whether cobalt (II) ions released from the interaction between WC-Co particles and oxygen contribute to the genotoxicity of these particles is not known.

\section{Other cobalt compounds}

A mortality study was conducted among Danish women exposed to poorly soluble cobaltaluminate spinel in a porcelain factory. ${ }^{36}$ The airborne cobalt concentrations in this plant were high (often $>1000 \mu \mathrm{g} / \mathrm{m}^{3}$ ). The standardised incidence rate of lung cancer was found to be higher than expected from national rates in both the control and the exposed group (1.99 and 2.35, respectively). The exposed group had a non-significantly increased relative risk ratio of 1.2 (95\% CI 0.4 to 3.8$)$ compared with controls. No relation with duration or intensity of exposure could be found. The influence of smoking could not be taken into account in this study. Among the eight cases of lung cancer identified in the exposed cohort, three had been exposed to cobalt spinel for less than 3 months only. Overall, this study does not 
Table 3 Update of the scientific evidence for the genotoxicity and carcinogenicity of cobalt compounds (see text for references)

\begin{tabular}{|c|c|c|c|c|}
\hline \multirow[b]{2}{*}{ Cobalt species } & \multicolumn{2}{|l|}{ Genotoxicity } & \multicolumn{2}{|l|}{ Carcinogenicity } \\
\hline & In vitro & In vivo & Animals & Humans \\
\hline Cobalt metal & $\begin{array}{l}\text { Some evidence of DNA damage } \\
\text { (alkali labile or strand breaks or } \\
\text { both induced by Co metal } \\
\text { particles, micronuclei in human } \\
\text { lymphocytes). Interference with } \\
\text { repair processes of damaged DNA }\end{array}$ & $\begin{array}{l}\text { Big blue mouse bioassay: no } \\
\text { increased frequency of mutations } \\
\text { (sensitivity of the model is } \\
\text { questioned) }\end{array}$ & $\begin{array}{l}\text { No induction of tumours after } \\
\text { injection of cobalt-chromium } \\
\text { molybdene powder in mice }\end{array}$ & $\begin{array}{l}\text { No increased risk of lung } \\
\text { cancer in a cohort of } \\
\text { workers from a } \\
\text { electrochemical plant }\end{array}$ \\
\hline Hard metal particles & $\begin{array}{l}\text { Evidence of DNA damage (strand } \\
\text { breaks, micronuclei in human } \\
\text { lymphocytes). }\end{array}$ & $\begin{array}{l}\text { Big blue mouse bioassay: no } \\
\text { increased frequency of mutations } \\
\text { (sensitivity of the model is } \\
\text { questioned) }\end{array}$ & & $\begin{array}{l}\text { Evidence of an increased } \\
\text { risk of lung cancer in two } \\
\text { separate studies }\end{array}$ \\
\hline Cobalt (II) ions & $\begin{array}{l}\text { Genotoxic in prokaryotes and } \\
\text { eukaryotes } \\
\text { DNA damage by Fenton-like } \\
\text { mechanism } \\
\text { Inhibition of excision repair } \\
\text { process }\end{array}$ & $\begin{array}{l}\text { Oxidative damage in chromatin } \\
\text { after intraperitoneal injection in } \\
\text { mice }\end{array}$ & $\begin{array}{l}\text { Clear evidence of carcinogenicity } \\
\text { in rat and mice (lung neoplasms) }\end{array}$ & \\
\hline Cobalt-aluminate spinel & & & & $\begin{array}{l}\text { No solid evidence of an } \\
\text { increased risk of lung } \\
\text { cancer in a single study }\end{array}$ \\
\hline
\end{tabular}

provide solid evidence of an increased risk of lung cancer associated with exposure to cobalt spinel.

No study examining the genotoxic or carcinogenic activity of cobalt oxides $(\mathrm{CoO}$ or $\mathrm{Co}_{3} \mathrm{O}_{4}$ ) was found in the literature published since the 1991 IARC evaluation.

\section{General conclusions}

An evaluation of the recent scientific evidence indicates that, although many areas of uncertainty remain, an assessment of the carcinogenicity of cobalt and its compounds requires a

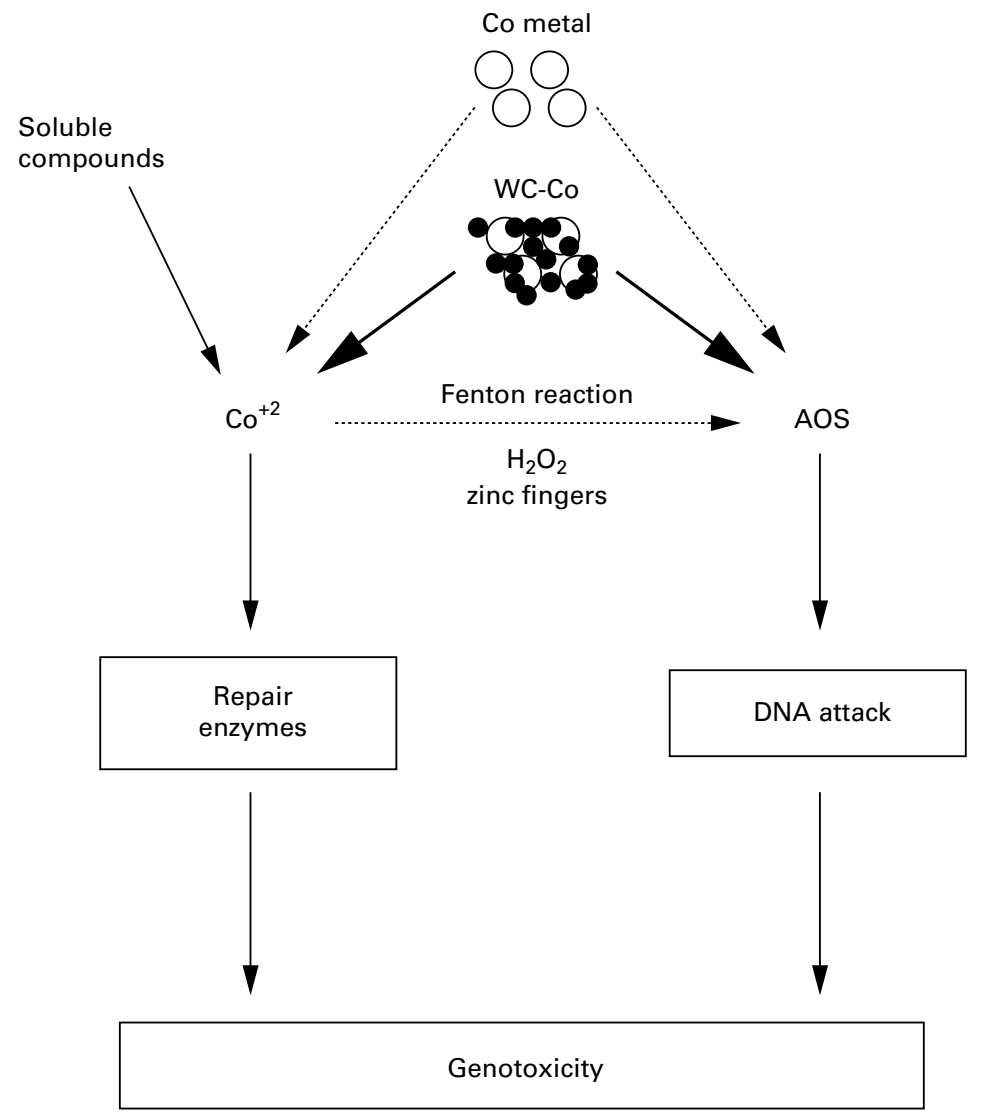

Figure 1 Mechanisms of cobalt genotoxicity. clear distinction between the different compounds of the element and needs to take into account the different mechanisms involved (table 3 and fig 1).

- There is evidence that soluble cobalt (II) cations exert a genotoxic and carcinogenic activity in vitro and in vivo in experimental systems but evidence in humans is lacking.

- Experimental data indicate some evidence of a genotoxic potential for cobalt metal in vitro in human lymphocytes but there is no evidence available about carcinogenic potential.

- There is evidence that hard metal particles exert a genotoxic and carcinogenic activity in vitro and in human studies, respectively.

- There is insufficient information for cobalt oxides and other compounds.

Although this assessment may be of interest to scientists involved in metal carcinogenesis to better focus further research, it also considers the possibility for occupational physicians, hygienists, and regulators to achieve a better risk assessment by taking into account metal speciation and mechanisms of mutagenesis or carcinogenesis.

1 Lison D. Human toxicity of cobalt-containing dust and experimental studies on the mechanism of interstitial lung disease (hard metal disease). Crit Rev Toxicol 1996;26:585616.

2 Linnainmaa $M$, Kiilunen $M$. Urinary cobalt as a measure of exposure in the wet sharpening of hard metal and stellite blades. Int Arch Occup Environ Health 1997;69:193-200.

3 Cobalt and cobalt compounds. IARC Monogr Eval Carcinog Cobalt and cobalt compounds.

4 Merritt K, Brown SA, Sharkey NA. The binding of metal salts and corrosion products to cells and proteins in vitro. $\mathcal{F}$

5 Nackerdien Z, Kasprzak KS, Rao G, et al. Nickel(II) and cobalt(II) dependent damage by hydrogen peroxide to the DNA bases in isolated human chromatin. Cancer Res 1991; 51:5837-42

6 Lloyd DR, Phillips DH, Carmichael PL. Generation of putative intrastrand cross-links and strand breaks in DNA by transition metal ion-mediated oxygen radical attack. Chem Res Toxicol 1997;10:393-400.

7 Kawanishi S, Inoue S, Yamamoto K. Active oxygen species in DNA damage induced by carcinogenic metal compounds. Environ Health Perspect 1994;102(suppl 3):17-20.

8 Mao Y, Liu KJ, Jiang JJ, et al. Generation of reactive oxygen species by $\mathrm{Co}$ (II) from $\mathrm{H}_{2} \mathrm{O}_{2}$ in the presence of chelators in species by $\mathrm{Co}(\mathrm{II})$ from $\mathrm{H}_{2} \mathrm{O}_{2}$ in the presence of chelators in lation. F Toxicol Environ Health 1996;47:61-75.

lation. F Toxicol Environ Health 1996;47:61-75.

proting proteins and its relevance to mutagenicity and carcinogenicity through free radical generation. Nutrition 1995;11: 646-9. 
10 Hartwig A, Snyder RD, Schlepegrell R, et al. Modulation by $\mathrm{Co}$ (II) of UV-induced DNA repair, mutagenesis and sisterchromatid exchanges in mammalian cells. Mutat Res 1991; 248:177-85.

11 Kasten U, Mullenders LH, Hartwig A. Cobalt(II) inhibits the incision and the polymerization step of nucleotide excision repair in human fibroblasts. Mutat Res 1997;383:81-9.

12 Asmuss $\mathrm{M}$, Mullenders $\mathrm{LH}$, Hartwig A. Interference by toxic metal compounds with isolated zinc finger DNA repair proteins. Toxicol Lett 2000;112-113, 227-31.

13 Palecek E, Brazdova $M$, Cernocka $H$, et al. Effect of transition metals on binding of $\mathrm{p} 53$ protein to supercoiled DNA and to consensus sequence in DNA fragments. Oncogene 1999;18:3617-25.

14 Meplan C, Richard M-J, Hainaut P. Metalloregulation of the tumor suppressor protein $\mathrm{p} 53$ : zinc mediates the renathe turo 153 after prose turation of p53 after exposure to metal chela

15 Kasprzak KS, Zastawny TH, North SL, et al. Oxidative DNA base damage in renal, hepatic, and pulmonary chroDNA base damage in renal, hepatic, and pulmonary chromatin of rats after intraperitoneal injection

16 Anard D, Kirsch Volders M, Elhajouji A, et al. In vitro genotoxic effects of hard metal particles assessed by alkaline single cell gel and elution assays. Carcinogenesis 1997;18: $177-84$.

17 De Boeck M, Lison D, Kirsch Volders M. Evaluation of the in vitro direct and indirect genotoxic effects of cobalt compounds using the alkaline comet assay. Influence of interdonor and interexperimental variability. Carcinogenesis 1998;19:2021-9.

18 Palit S, Sharma A, Talukder G. Chromosomal aberrations induced by cobaltous chloride in mice in vivo. Biol Trace Elem Res 1991:29:139-45.

19 Goldwasser E, Jacobson LO, Fried W, et al. Studies on erythropoiesis, $\mathrm{V}$. The effect of cobalt on the production of erythropoietin. Blood 1958;13:55-60

20 Suzuki Y, Shimizu H, Nagae Y, et al. Micronucleus test and erythropoiesis: effect of cobalt on the induction of erythropoiesis: effect of cobalt on the induction of 101-6.

21 Bucher JR, Hailey JR, Roycroft JR, et al. Inhalation toxicity and carcinogenicity studies of cobalt sulfate. Toxicol Sci 1999;49:56-67.

22 Borm PJ, Driscoll K. Particles, inflammation and respiratory tract carcinogenesis. Toxicol Lett 1996;88:109-13.

23 Lison D, Lauwerys R. Study of the mechanism responsible for the elective toxicity of tungsten carbide-cobalt powder toward macrophages. Toxicol Lett 1992;60:203-10.
24 Lison D, Carbonnelle P, Mollo L, et al. Physicochemical mechanism of the interaction between cobalt metal and carbide particles to generate toxic activated oxygen species. Chem Res Toxicol 1995;8:600-6.

25 Van Goethem F, Lison D, Kirsch Volders M. Comparative evaluation of the in vitro micronucleus test and the alkaline single cell gel electrophoresis assay for the detection of DNA damaging agents: genotoxic effects of cobalt powder, tungsten carbide and cobalt-tungsten carbide. Mutat Res 1997;392:31-43.

26 De Boeck M, Lardau S, Buchet JP, et al. Absence of significant genotoxicity in lymphocytes and urine from workers exposed to moderate levels of cobalt-containing dust: a cross sectional study. Environ Mol Mutagen 2000;36:15160.

27 American Conference of Governmental Industrial Hygienists. Threshold limit values for chemical substances and physical agents and biological exposure indices. Cincinnati, $\mathrm{OH}$ : ACGIH, 2000.

28 Lewis CG, Belniak RM, Plowman MC, et al. Intraarticular carcinogenesis bioassays of CoCrMo and TiAlV alloys in rats. F Arthroplasty 1995;10:75-82.

29 Mur JM, Moulin JJ, Charruyer-Seinerra MP, et al. A cohort mortality study among cobalt and sodium workers in an electrochemical plant. Am f Ind Med 1987;11:75-81.

30 Moulin JJ, Wild P, Mur JM, et al. A mortality study of cobalt production workers: an extension of the follow-up. $A m \mathcal{F}$ Ind Med 1993;23:281-8.

31 Hagmar L, Bonassi S, Stromberg U, et al. Chromosomal aberrations in lymphocytes predict human cancer: a report from the European Study Group on Cytogenetic Biomarkers and Health (ESCH). Cancer Res 1998;58:4117-21.

32 Moulin JJ, Wild P, Romazini S, et al. Lung cancer risk in hard-metal workers. Am f Epidemiol 1998;148:241-8.

33 Hogstedt C, Alexandersson R. Mortality study among workers from the hard metal industry (in Swedish). Arbete och Hälsa 1990;211-20.

34 Lasfargues G, Wild P, Moulin JJ, et al. Lung cancer mortality in a French cohort of hard-metal workers. $A m \mathcal{F}$ Ind Med 1994;26:585-95.

35 Wild P, Perdrix A, Romazini S, et al. Lung cancer mortality in a site producing hard metals. Occup Environ Med 2000;57:568-73

36 Tuchsen F, Jensen MV, Villadsen E, et al. Incidence of lung cancer among cobalt-exposed women. Scand $\mathcal{F}$ Work Environ Health 1996;22:444-50.

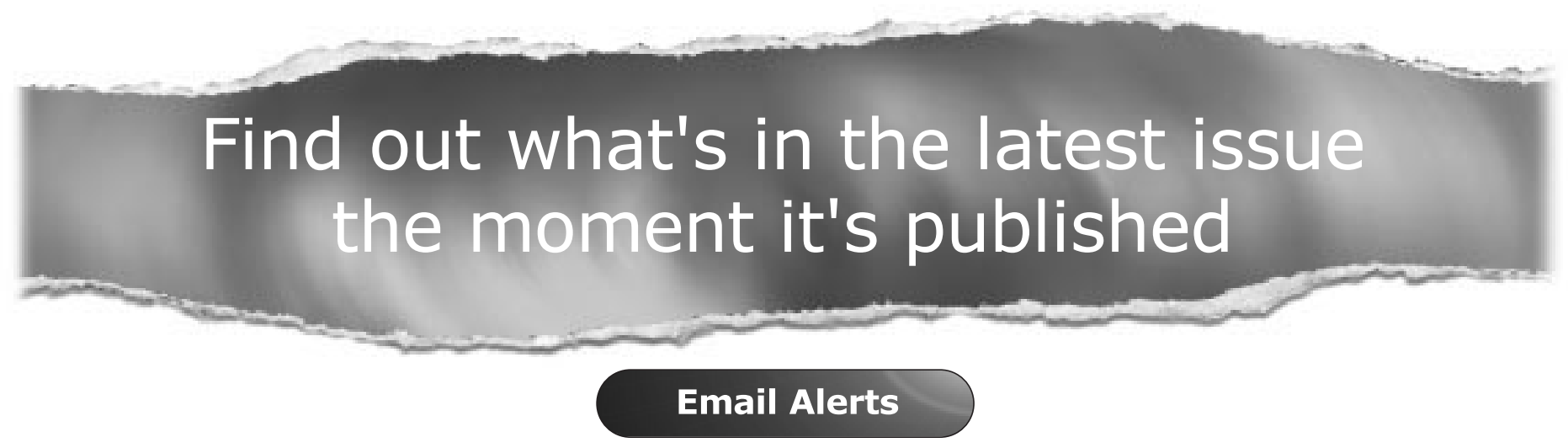

Sign up to receive the table of contents by email every month. You can select from three alerts:

Table of Contents (full), TOC Awareness (notice only); Occupational and Environmental Medicine related announcements.

www.occenvmed.com 